\title{
MODEL PERLINDUNGAN KONSUMEN DALAM TRANSAKSI BERBENTUK KLAUSULA BAKU
}

\section{IN TRANSACTIONS WITH RAIN CLAUSULA IN TRANSACTIONS OF STANDARD CLAUSES}

\author{
JJ Gilalo'ia dan Nurwati $^{1}$ \\ 1 Program Studi Ilmu Hukum, Fakultas Hukum, Universitas Djuanda Bogor, Jl. Tol Ciawi No. 1 \\ Kotak Pos 35 Ciawi Bogor 16720 \\ a Korespondensi: Jacobus Jopie Gilalo, Email: jopie.gilalo@unida.ac.id \\ (Diterima: 11-01-2017; Ditelaah: 12-01-2017; Disetujui: 28-02-2017)
}

\begin{abstract}
This research is to know the shape of consumer protection in commercial transactions for goods and / or services in the city of Bogor, and to develop models of standard clauses in a voucher that gives protection to the consumer. As for the long-term goals to be achieved from this research is to find out a model standard clause in the transaction of goods and / or services in accordance with Act No. 8 Year 1999 on Consumer Protection. The method used in this research is descriptive research, then in analyzing the data this study used descriptive qualitative, which an analysis of that nature to explain or describe the findings apply to the empirical juridical / sociological, then associated with the reality of the matter in society and ultimately be concluded, that formulated a model of consumer protection in the form of transaction in standard clause as according to the consumer protection Act by taking an example in the city of Bogor. Targeted results from this study are accredited scientific journal publications and the creation of an analysis result of the transaction model of consumer protection in the form of standard clauses in the city of Bogor. With such formulation may be a basic consideration in giving a protection for the consumer. And that became the additional output from this research can be instructional materials, especially the enrichment of material, in particular additional teaching materials on the disciplines of law and may also be used by the personnel to the academic development of consumer protection law.
\end{abstract}

Keywords: model of consumer protection, transactions, standard clause.

\section{ABSTRAK}

Penelitian ini untuk mengetahui bentuk-bentuk perlindungan konsumen dalam transaksi perniagaan atas barang dan/atau jasa di Kota Bogor, dan untuk mengembangkan model klausula baku dalam bukti transaksi yang memberi perlindungan kepada konsumen. Adapun tujuan jangka panjang yang akan dicapai dari hasil penelitian ini adalah untuk mengetahui suatu model klausula baku dalam transaksi barang dan/atau jasa yang sesuai dengan UndangUndang Nomor 8 Tahun 1999 tentang Perlindungan Konsumen. Metode penelitian yang digunakan dalam penelitian ini yaitu dengan jenis penelitian deskriptif, maka dalam menganalisis data penelitian ini, digunakan deskriptif kualitatif, yaitu suatu analisis yang sifatnya menjelaskan atau menggambarkan mengenai penemuan-penemuan yang berlaku dengan yuridis empiris/sosiologis, kemudian dikaitkan dengan kenyataan yang terjadi di masyarakat dan akhirnya diambil kesimpulan, yaitu terumusnya model perlindungan konsumen dalam transaksi berbentuk Klausula Baku sebagaimana menurut Undang-Undang Perlindungan Konsumen dengan mengambil contoh di kota Bogor. Hasil yang ditargetkan dari penelitian ini adalah publikasi jurnal ilmiah terakreditasi dan terciptanya suatu hasil analisis 
mengenai model perlindungan konsumen dalam transaksi berbentuk klausula baku di kota Bogor. Dengan rumusan tersebut dapat menjadi dasar pertimbangan dalam memberi suatu perlindungan bagi konsumen. Dan yang menjadi luaran tambahan dari hasil penelitian ini dapat menjadi bahan ajar terutama pengayaan materi, khususnya tambahan bahan ajar pada disiplin ilmu hukum dan dapat pula dipergunakan oleh insan akademika guna pengembangan hukum perlindungan konsumen.

Kata kunci: klausula baku, model perlindungan konsumen, transaksi.

Gilalo JJ dan Nurwati. 2017. Model perlindungan konsumen dalam transaksi berbentuk klausula baku. Jurnal Sosial Humaniora 8(1): 14 - 28.

\section{PENDAHULUAN}

Setiap hari manusia bertransaksi untuk memenuhi kebutuhan hidupnya, baik terhadap barang dan/atau jasa yang ada di pasaran. Namun, dalam setiap transaksi yang dilakukannya sebagai konsumen apakah telah memberi perlindungan terhadapnya. Tanpa disadari oleh konsumen apa yang telah diterimanya belum tentu sesuai dengan keinginannya. Keinginan atas barang dan/atau jasa yang telah dibayarkannya harus diterimanya karena adanya ketentuan yang secara sepihak telah mengikatnya sehingga hak untuk menuntut atas barang dan/atau jasa yang telah diterima dan dinikmatinya tidak sesuai dengan keadaan sebenarnya.

Dunia bisnis belakangan ini mengalami perkembangan yang sangat pesat, ditandai oleh banyaknya produk barang dan/atau pelayanan jasa yang ditawarkan oleh pelaku usaha kepada masyarakat selaku konsumen baik melalui iklan, promosi, maupun melalui event penawaran secara langsung dan bisnis on-line, yang memberikan kemudahan bagi konsumen untuk memilih barang dan/atau jasa berdasarkan kebutuhan dan keinginan konsumen.

Ketika keputusan konsumen telah dijatuhkan untuk memilih barang dan/atau jasa yang ditawarkan, maka telah terjadi transaksi perdagangan antara pihak pelaku usaha dengan konsumen. Dengan demikian transaksi tersebut merupakan hubungan jual- beli dan didalam nya telah terikat adanya perjanjian. Namun jika konsumen tidak berhati-hati memilih barang dan/atau jasa yang ditawarkan kepadanya, hal ini dapat menjadikan konsumen sebagai objek eksploitasi para pelaku usaha yang tidak bertanggung jawab. Tanpa disadari, konsumen menerima begitu saja barang yang diberikan kepadanya tanpa mengetahui apakah produk yang dikonsumsinya itu baik atau tidak.

Di samping itu, banyak pelaku usaha yang menggunakan klausula baku untuk mempercepat proses perjanjian jual beli yang isinya terlebih dahulu ditentukan oleh pelaku usaha tanpa ada negosiasi dengan konsumen. Biasanya klausula baku yang ditetapkan pelaku usaha berisi hal-hal yang berkenaan dengan kewajiban konsumen tanpa menjelaskan hak yang akan diperolehnya secara jelas dan bersifat menghilangkan tanggung jawab pelaku usaha (produsen), sehingga ketika konsumen merasa tidak puas dengan barang yang dibelinya dari pelaku usaha, konsumen tidak dapat mengembalikannya kepada pelaku usaha karena hal tersebut telah dicantumkan dalam klausula baku perjanjian jual beli yang menyatakan: "Barang yang sudah dibeli tidak dapat dikembalikan lagi". Ada juga pelaku usaha yang mau menerima kembali barang yang telah dijual tetapi dengan proses yang begitu panjang dan rumit, misalnya konsumen disuruh untuk membuktikan bahwa kerusakan barang memang sudah ada sejak barang tersebut belum berpindah ke tangan konsumen, padahal pelaku usaha mengerti bahwa pengetahuan konsumen seputar produksi barang sangat minim. 
Bentuk klausula baku sebagai model standar dalam perdagangan (niaga), telah muncul pada setiap level transaksi bisnis, mulai dari transaksi bisnis yang berskala besar sampai pada "kaki lima". Munculnya klausula baku sebenarnya merupakan akibat tidak langsung dari introduksi asas kebebasan berkontrak (Pasal 1338 Burgelijke Wetboek). Tidak adanya restriksirestriksi substsansial yang mampu menyeimbangkan posisi tawar (bargaining position) di antara para pihak yang mengadakan transaksi, maka melahirkan penguasaan oleh satu pihak dan keterpaksaan pada pihak lainnya.

Dalam bertransaksi pada aktivitas perniagaan bentuk klausula baku digunakan oleh produsen terhadap konsumen, di mana substansi dokumen yang dikeluarkan oleh produsen telah ditentukannya sehingga mempersempit ruang tawar maupun tuntutan (klaim) dari konsumen terhadap konsumen (Sjahputra 2010).

Undang-Undang Nomor 8 tahun 1999 tentang Perlindungan Konsumen (UndangUndang Perlindungan Konsumen) yang telah berlaku sejak tanggal 20 April 2000, merupakan piranti hukum yang berfungsi sebagai landasan untuk menjamin adanya kepastian hukum dan memberi perlindungan kepada konsumen (Anonim 2003). Namun, dalam kenyataannya, kerapkali ditemukan perbuatan dari produsen sebagai pelaku usaha yang dilarang yaitu ketentuan klausula baku dalam memberikan dokumen dan/atau perjanjian baku/standar sebagai bukti transaksi yang isinya menimbulkan kerugian pada konsumen.

Kondisi konsumen dalam bertransaksi dengan produsen (pelaku usaha) masih sangat lemah posisinya dibandingkan dengan posisi produsen. Hal ini tampak dari kondisi yang tidak seimbang antara konsumen dengan produsen. Kondisi ini perlu adanya pemberdayaan konsumen agar posisinya tidak selalu pada pihak yang dirugikan.
Pemberdayaan konsumen dapat dilakukan melalui penerapan hukum perlindungan konsumen yang memadai, di mana hukum perlindungan konsumen ini menjadi relevan pada tiga tahap transaksi konsumen, yaitu pra-pembelian, saat pembelian, dan purna pembelian (Miru 2011).

Pada tahap pertama konsumen perlu memilih barang dan/atau jasa sesuai dengan kebutuhannya dan keinginannya bukan karena pengaruh dari lingkungan luar, serta melihat kualitas maupun kuantitas pilihannya. Tahap kedua, konsumen harus mendapatkan informasi yang jelas dan benar untuk setiap transaksi barang dan/atau jasa yang dilakukannya dari produsen sehingga terhindar dari tindakan yang merugikannya. Sedangkan ketiga, konsumen mendapatkan barang dan/atau jasa yang bermutu atau pelayanan yang baik, serta tanda bukti bahwa konsumen telah mendapatkan barang atau pelayanan. Hal ini patut didapatkan oleh konsumen apabila dalam pelaksanaan bertransaksi timbul ekses yang merugikan dikemudian hari dapat memperoleh hakhaknya (Direktorat Perlindungan Konsumen 2001).

Bentuk-bentuk klausula baku dalam setiap dokumen dan/atau perjanjian baku/standar yang ditemukan dalam bertransaksi sebagai bukti pembayaran maupun pengikatan antara konsumen dengan produsen dapat menutup perlindungan konsumen terhadap kesehatan/hartanya karena penggunaan barang dengan kualitas yang di bawah standar atau rendah dari pada nilai harga yang dibayarnya (Miru 2011).

Selain itu, isi klausula baku yang sering melemahkan posisi tawar konsumen, bentuk dan tata letak klausula baku itu sendiri umumnya dikondisikan untuk sulit di baca atau dipahami konsumen. Pencantuman klausula baku dengan huruf yang sulit dimengerti merupakan salah satu kiat yang sering digunakan pelaku usaha. Tata letak klausula baku yang demikian, akan mendorong konsumen untuk sesegera mungkin mengambil keputusan karena tidak 
memberikan kesempatan bagi konsumen untuk melakukan penelitian dan memahaminya serta memberikan tekanan psikologis yang mempengaruhi rasionalitasnya dalam mengambil keputusan untuk membeli.

Maka perlu model perlindungan konsumen dalam bertransaksi dengan bentuk klausula baku yang dapat melindungi konsumen dari penggunaan yang tidak sesuai dengan standar yang ditentukan dalam Undang-Undang Perlindungan Konsumen, adalah Pasal 18 ayat (1) dan ayat (2), yang menentukan setiap aturan atau ketentuan dan syarat-syarat yang telah dipersiapkan dan ditetapkan terlebih dahulu secara sepihak oleh pelaku usaha yang dituangkan dalam suatu dokumen dan/atau perjanjian yang mengikat dan wajib dipenuhi oleh konsumen tidak dibenarkan.

\section{MATERI DAN METODE}

\section{Materi}

Berbagai kajian tentang perlindungan konsumen telah banyak dilakukan lembagalembaga perlindungan konsumen maupun di kalangan akademisi yang menyangkut klausula baku dengan berbagai transaksi (Tobing 2007). Namun, dari kajiankajian yang telah dilakukan tersebut belum memberikan suatu model perlindungan konsumen dalam transaksi berbentuk klausula baku yang dapat diterima baik oleh konsumen itu sendiri maupun bagi produsen/pelaku usaha.

Pemerintah RI melalui Direktorat Perrlindungan Konsumen, Direktorat Jenderal Perdagangan Dalam Negeri, Departemen Perindustrian dan Perdagangan, pada tahun 2002-2003 telah menerbitkan baku saku pedoman klausula baku di bidang jasa telekomumnikasi dan perbankan (Direktorat Perlindungan Konsumen 2001) (Anonim 2003), akan tetapi dalam buku saku tersebut, tidak memberikan secara jelas dan terang suatu model klausula baku dalam transaksi di bidang jasa dimaksud. Penginformasian yang diberikan oleh pihak pemerintah itu hanya memberi pengertian dan batasan klausula baku yang dilarang oleh UUPK, serta kewajiban, hak dan tanggung jawab konsumen.

Begitu pula Bank Indonesia, dalam Himpunan Ketentuan Perlindungan Nasabah, yang berisi Peraturan-peraturan dan Surat Edaran yang dikeluarkan oleh Bank Indonesia yang menyangkut Mediasi Perbankan, Penyelesesaian pengaduan nasabah dan Transparasi informasi produk bank dan penggunaan data pribadi nasabah. Ketentuanketentuan yang diterbitkan oleh Bank Indonesia ini tidak memberikan model transaksi di bidang perbankan berbentuk klausula baku yang disesuaikan dengan ketentuan mengenai klausula yang diatur dalam UUPK, namun hanya ketentuan tentang mediasi perbankan atas penyelesaian pengaduan dari nasabah bank.

Undang-undang tentang perlindungan konsumen tidak memberikan definisi tentang perjanjian baku dan/atau pencantuman klausula baku dalam setiap dokumen atau perjanjian yang dibuat oleh pelaku usaha (produsen), tetapi merumuskan klasula baku sebagai: "Setiap aturan atau ketentuan dan syarat-syarat yang telah dipersiapkan dan ditetapkan terlebih dahulu secara sepihak oleh pelaku usaha yang dituangkan dalam suatu dokumen dan/atau perjanjian yang mengikat dan wajib dipenuhi oleh konsumen" (Widjaja dan Yani 2008).

Ketentuan pencantuman klausula baku dalam UUPK hanya diatur 1 (satu) pasal saja, yaitu Pasal 18. Ketentuan ini pada prinsipnya mengatur 2 (dua) macam larangan yang diberlakukan bagi para pelaku usaha yang membuat perjanjian baku dan/atau mencantumkan klausula baku dalam dokumen yang dibuatnya. ${ }^{11}$ Pasal 18 ayat (1)

UUPK mengatur larangan pencantuman klausula baku, dan Pasal 18 ayat (2) UUPK mengatur "bentuk" atau "format", serta penulisan perjanjian baku yang dilarang.

Dalam ketentuan tersebut di atas dikatakan bahwa para pelaku usaha dalam menawarkan barang dan/atau jasa yang 
ditujukan untuk diperdagangkan dilarang membuat atau mencantumkan klausula baku pada setiap dokumen dan/atau perjanjian di mana klausula baku tersebut akan mengakibatkan:

1. Pengalihan tanggung jawab pelaku usaha;

2. Menyatakan bahwa pelaku usaha berhak menolak penyerahan kembali barang yang dibeli konsumen;

3. Menyatakan bahwa pelaku usaha berhak menolak penyerahan kembali uang yang dibayarkan atas barang dan/atau jasa yang dibeli oleh konsumen;

4. Menyatakan pemberian kuasa dari konsumen kepada pelaku usaha, baik secara langsung maupun tidak langsung untuk melakukan segala tindakan sepihak yang berkaitan dengan barang yang dibeli oleh konsumen secara angsuran;

5. Mengatur perihal pembuktian atas hilangnya kegunaan barang ataupemanfaatan jasa yang dibeli oleh konsumen;

6. Memberi hak kepada pelaku usaha untuk mengurangi manfaat jasa atau mengurangi harta kekayaan konsumen yang menjadi objek jual beli jasa;

7. Menyatakan tunduknya konsumen kepada peraturan yang berupa aturan baru, tambahan, lanjutan, dan/atau pengubahan lanjutan yang dibuat sepihak oleh pelaku usaha dalam masa konsumen memanfaatkan jasa yang dibelinya;

8. Menyatakan bahwa konsumen memberi kuasa kepada pelaku usaha untuk pembebanan hak tanggungan, hak gadai, atau hak jaminan terhadap barang yang dibeli oleh konsumen secara angsuran.

Akibat-akibat yang disebutkan tersebut terdapat dalam Widjaja dan Yani (2008). Selanjutnya, dalam Pasal 18 ayat (2) dijelaskan bahwa pelaku usaha dilarang mencantumkan klausula baku yang letak atau bentuknya sulit terlihat atau tidak dapat dibaca secara jelas, atau yang pengungkapannya sulit dimengerti.

Konsekuensi yuridis atas pelanggaran ketentuan tersebut sebagaimana dikatakan dalam Pasal 18 ayat (3) UUPK adalah batal demi hukum bagi setiap klausula baku yang telah ditetapkan oleh pelaku usaha pada dokumen atau perjanjian yang memuat ketentuan yang disebutkan dalam Pasal 18 ayat (1) dan (2) UUPK. Berarti dokumen dan/atau perjanjian yang memuat ketentuan mengenai klausula baku yang dilarang oleh ketentuan pencantuman klausula baku dalam UUPK ini dianggap tidak pernah ada dan mengikat para pihak, yaitu antara pelaku usaha dengan konsumen yang melaksanakan transaksi perniagaan barang dan/atau jasa yang dilakukan (Widjaja dan Yani 2008).

Agar dokumen dan/atau perjanjian baku dalam transaksi perniagaan barang dan/atau jasa yang dikeluarkan oleh pelaku usaha, maka diwajibkan untuk menyesuaikan klausula baku yang bertentangan dengan UUPK, karena dalam undang-undang ini tidak melarang pula bagi pelaku usaha untuk membuat dokumen dan/atau perjanjian baku yang memuat klasusula baku.

\section{Metode}

\section{Metode Penelitian}

Metode penelitian adalah cara atau proses pemeriksaan atau penyelidikan yang menggunakan pemalaran berfikir yang logis analitis (logika), berdasarkan dalil-dalil, rumus-rumus dan teori suatu ilmu tentang gejala-gejala atau peristiwa hukum tertentu (Ibrahim 2006). Penelitian hukum pada dasarnya ialah kegiatan penyelesaian masalah. Adapun cara pemecahan masalah dilakukan oleh peneliti dengan jalan mengidentifikasi dan mengkualifikasi faktafakta dan mencari norma hukum yang berlaku untuk kemudian mengambil kesimpulan berdasarkan fakta-fakta dan norma hukum tersebut.

Penelitian hukum dilakukan untuk mencari pemecahan atau isu hukum yang timbul. Oleh karena itulah penelitian hukum 
merupakan suatu penelitian di dalam kerangka know how di dalam hukum (Marzuki 2005). Hasil yang dicapai adalah untuk memberikan perskripsi mengenai apa yang seyogyanya atas isu yang diajukan. Penelitian hukum juga berarti suatu proses untuk menemukan aturan hukum, prinsipprinsip hukum, maupun doktrindoktrin hukum guna menjawab isu hukum yang dihadapi.

\section{Jenis Penelitian}

Jenis penelitian yang digunakan dalam penelitian ini adalah deskriptif, yaitu jenis penelitian yang sifatnya mendeskripsikan atau menjelaskan peraturan-peraturan yang ada dan saat ini berlaku sebagai hukum positif dan bertujuan untuk memahami penerapan norma-norma hukum terhadap fakta-fakta.

Adapun pendekatan masalah yang dipergunakan dalam penelitian ini adalah pendekatan yuridis empiris/sosiologis, yaitu pendekatan terhadap hukum sebagai suatu norma atau kaidah dan pendekatan terhadap masyarakat dalam arti melihat realita yang ada di masyarakat untuk identifikasi terhadap faktor-faktor yang berperan dalam peristiwa hukum yang bersangkutan. Pilihan tersebut dilakukan agar memperoleh gambaran yang dihasilkan tidak bias normatif dan tidak bias faktual.

Berdasarkan tipe penelitian yang digunakan untuk melakukan penelitian ini adalah penelitian yuridis empiris/sosiologis, maka pendekatan masalah yang digunakan peneliti adalah pendekatan perundangundangan (statute approach), yaitu UndangUndang Nomor 8 Tahun 1999 tentang Perlindungan Konsumen, khususnya ketentuan Pasal 18 ayat (1) dan ayat (2) Pencantuman Klausula Baku yang terkait dengan permasalahan yang diteliti yaitu penggunaan model klausula baku sebagai tanda transaksi perniagaan dengan pendekatan melalui wawancara (interview) terhadap lembaga maupun instansi yang terkait permasalahan yang diteliti.

\section{Teknik Analisis Data}

Menganalisis data merupakan suatu langkah yang kritis dalam penelitian karena dalam penelitian peneliti harus memastikan pola analitis yang akan digunakan. Analisis data dilakukan secara kualitatif yang merupakan cara untuk menghasilkan deskriptif. Data yang dianalisis mulai dari hasil kualitatif, kemudian mengklasifikasikan data dapat diformulasikan berdasarkan permasalahan penelitian, baru kemudian ditarik kesimpulan.

Dalam menganalisis data penelitian ini, peneliti mempergunakan analisis deskriptif kualitatif, yaitu suatu analisis yang sifatnya menjelaskan atau menggambarkan mengenai penemuan-penemuan yang berlaku, kemudian dikaitkan dengan kenyataan yang terjadi dimasyarakat dan akhirnya diambil kesimpulan.

\section{HASIL DAN PEMBAHASAN}

\section{Hasil}

\section{Klausula Baku}

Berbagai kajian tentang perlindungan konsumen telah banyak dilakukan lembagalembaga perlindungan konsumen maupun di kalangan akademisi yang menyangkut klausula baku dengan berbagai transaksi (Tobing 2007). Namun, dari kajian-kajian yang telah dilakukan tersebut belum memberikan suatu model perlindungan konsumen dalam transaksi berbentuk klausula baku yang dapat diterima baik oleh konsumen itu sendiri maupun bagi produsen/pelaku usaha.

Pemerintah Republik Indonesia melalui Direktorat Perlindungan Konsumen, Direktorat Jenderal Perdagangan Dalam Negeri, Departemen Perindustrian dan Perdagangan (sekarang Kementerian Perdagangan), pada tahun 2002-2003 telah menerbitkan buku saku pedoman klausula baku di bidang jasa telekomunikasi dan perbankan (Direktorat Perlindungan Konsumen 2002) (Anonim 2003), akan 
tetapi dalam buku saku tersebut, tidak memberikan secara jelas dan terang suatu model klausula baku dalam transaksi di bidang jasa dimaksud. Penginformasian yang diberikan oleh pihak pemerintah itu hanya memberi pengertian dan batasan klausula baku yang dilarang oleh Undang-Undang Perlindungan Konsumen, serta kewajiban, hak dan tanggung jawab konsumen.

Begitu pula Bank Indonesia, dalam Himpunan Ketentuan Perlindungan Nasabah, yang berisi Peraturan-peraturan dan Surat Edaran yang dikeluarkan oleh Bank Indonesia yang menyangkut Mediasi Perbankan, Penyelesaian pengaduan nasabah dan Transparasi informasi produk bank dan penggunaan data pribadi nasabah. Ketentuan-ketentuan yang diterbitkan oleh Bank Indonesia ini tidak memberikan model transaksi di bidang perbankan berbentuk klausula baku yang disesuaikan dengan ketentuan mengenai klausula yang diatur dalam Undang-Undang Perlindungan Konsumen, namun hanya ketentuan tentang mediasi perbankan atas penyelesaian pengaduan dari nasabah bank.

Undang-undang tentang perlindungan konsumen tidak memberikan definisi tentang perjanjian baku dan/atau pencantuman klausula baku dalam setiap dokumen atau perjanjian yang dibuat oleh pelaku usaha (produsen), tetapi merumuskan klausula baku dalam ketentuan Pasal 1 angka 10, menyatakan sebagai: "Setiap aturan atau ketentuan dan syaratsyarat yang telah dipersiapkan dan ditetapkan terlebih dahulu secara sepihak oleh pelaku usaha yang dituangkan dalam suatu dokumen dan/atau perjanjian yang mengikat dan wajib dipenuhi oleh konsumen".

Ketentuan pencantuman klausula baku dalam Undang-Undang Perlindungan Konsumen hanya diatur 1 (satu) pasal saja, yaitu Pasal 18. Ketentuan ini, pada prinsipnya mengatur 2 (dua) macam larangan yang diberlakukan bagi para pelaku usaha yang membuat perjanjian baku dan/atau mencantumkan klausula baku dalam dokumen yang dibuatnya (Widjaja dan Yani 2008). Pasal 18 ayat (1) UndangUndang Perlindungan Konsumen mengatur larangan pencantuman klausula baku, dan Pasal 18 ayat (2) Undang-Undang Perlindungan Konsumen mengatur "bentuk" atau "format", serta penulisan perjanjian baku yang dilarang.

Dalam ketentuan tersebut di atas dikatakan bahwa para pelaku usaha dalam menawarkan barang dan/atau jasa yang ditujukan untuk diperdagangkan dilarang membuat atau mencantumkan klausula baku pada setiap dokumen dan/atau perjanjian di mana klausula baku tersebut akan mengakibatkan:

1. pengalihan tanggung jawab pelaku usaha;

2. menyatakan bahwa pelaku usaha berhak menolak penyerahan kembali barang yang dibeli konsumen;

3. menyatakan bahwa pelaku usaha berhak menolak penyerahan kembali uang yang dibayarkan atas barang dan/atau jasa yang dibeli oleh konsumen;

4. menyatakan pemberian kuasa dari konsumen kepada pelaku usaha, baik secara langsung maupun tidak langsung untuk melakukan segala tindakan sepihak yang berkaitan dengan barang yang dibeli oleh konsumen secara angsuran;

5. mengatur perihal pembuktian atas hilangnya kegunaan barang atau pemanfaatan jasa yang dibeli oleh konsumen;

6. memberi hak kepada pelaku usaha untuk mengurangi manfaat jasa atau mengurangi harta kekayaan konsumen yang menjadi objek jual beli jasa;

7. menyatakan tunduknya konsumen kepada peraturan yang berupa aturan baru, tambahan, lanjutan, dan/atau pengubahan lanjutan yang dibuat sepihak oleh pelaku usaha dalam masa konsumen memanfaatkan jasa yang dibelinya;

8. menyatakan bahwa konsumen memberi kuasa kepada pelaku usaha untuk 
pembebanan hak tanggungan, hak gadai, atau hak jaminan terhadap barang yang dibeli oleh konsumen secara angsuran.

Selanjutnya dalam Pasal 18 ayat (2) Undang-Undang Perlindungan Konsumen dijelaskan bahwa pelaku usaha dilarang mencantumkan klausula baku yang letak atau bentuknya sulit terlihat atau tidak dapat dibaca secara jelas, atau yang pengungkapannya sulit dimengerti.

Konsekuensi yuridis atas pelanggaran ketentuan tersebut sebagaimana dikatakan dalam Pasal 18 ayat (3) Undang-Undang Perlindungan Konsumen adalah batal demi hukum bagi setiap klausula baku yang telah ditetapkan oleh pelaku usaha pada dokumen atau perjanjian yang memuat ketentuan yang disebutkan dalam Pasal 18 ayat (1) dan (2) Undang-Undang Perlindungan Konsumen. Berarti dokumen dan/atau perjanjian yang memuat ketentuan mengenai klausula baku yang di larang oleh ketentuan pencantuman klausula baku dalam Undang-Undang Perlindungan Konsumen ini dianggap tidak pernah ada dan mengikat para pihak, yaitu antara pelaku usaha dengan konsumen yang melaksanakan transaksi perniagaan barang dan/atau jasa yang dilakukan (Widjaja dan Yani 2008).

Maka dokumen dan/atau perjanjian baku dalam transaksi perniagaan barang dan/atau jasa yang dikeluarkan oleh pelaku usaha diwajibkan untuk menyesuaikan dengan klausula baku Undang-Undang Perlindungan Konsumen, meskipun dalam Undang-undang ini tidak melarang pula bagi pelaku usaha untuk membuat dokumen dan/atau perjanjian baku yang memuat klausula baku. Beberapa contoh model klausula baku yang ditemukan sebagai perolehan data awal dalam penelitian ini, banyak ditemukan katakata atau berupa kalimat yang tertera di dalam tanda bukti pembayaran yang terdapat pada Gambar 1, Gambar 2, dan Gambar 3.

Barang yang sudah dibeli tidak bisa di kembalikan

Gambar 1 Contoh model klausula baku
Kerusakan/kebocoran setelah meter air (pipa persil) dan keselamatan meter air (hilang/rusak menjadi beban/tanggung jawab pelanggan.

Gambar 2 Contoh model klausula baku

\section{Perhatian:}

1. Simpanlah karcis ini baik-baik dan periksalah Barang-barang Anda sebelum turun!

2. Bagasi tidak dipungut biaya, hilang, tertukar menjadi Tanggung jawab penumpang.

3. Harga karcis sudah termasuk Asuransi JASA RAHARJA.

Gambar 3 Contoh model klausula baku

Model klausula baku terdiri atas 2 (dua) bentuk, yaitu, klausula baku yang tidak dilarang dan klausula baku yang dilarang. Kedua klausula baku tersebut merupakan bentuk persyaratan yang banyak dijumpai jika kita mendapatkan kuitansi, faktur, bon juga dalam kemasan barang atau tercantum dalam tempat produk tertentu, tanda parkir, tanda penitipan barang bahkan dicantumkan dalam papan-papan pengumuman (Siahaan 2005).

Model kedua klausula baku di atas sebagai persyaratan yang ditentukan secara sepihak oleh penjual (produsen) terhadap konsumen yang menyangkut ganti rugi, pembebasan dari tanggung jawab atau menyangkut jaminan-jaminan tertentu (Siahaan 2005). Karena yang membuat dan mempersiapkannya adalah pihak penjual atau pelaku usaha, maka klausula demikian tentu dibuat atas dasar yang lebih menguntungkan baginya. Padahal jika kita mengacu pada ketentuan Pasal 18 ayat (1) dan ayat (2) Undang-Undang Perlindungan Konsumen sebagaimana telah diuraikan di atas, kalau ditelaah lebih lanjut lagi dapat ditemukan 4 (empat) macam larangan pencantuman klausula baku di dalam dokumen yang bermodel standar (Priyono 2015) sebagai berikut. 
a. Isi klausula baku

Terdapat 8 (delapan) macam isi klausula baku yang dilarang untuk dicantumkan di dalam dokumen dalam model yang sudah baku (standar) sebagaimana disebutkan dalam Pasal 18 ayat (1) butir a sampai dengan $h$. Berhubungan dengan isi klausula baku yang dirumuskan dalam bentuk larangan, maka daftar kedelapan macam klausula baku itu dapat dinamakan daftar negatif klausula baku.

b. Letak klausula baku

Letak penempatan klausula baku dalam dokumen dalam model standar harus mudah terlihat oleh konsumen (eye catching). Contoh, klausula baku yang di cetak di belakang selembar formulir aplikasi dapat dikualifikasi sebagai sulit terlihat oleh konsumen. Bagi yang menawarkan barang dan/atau jasa secara digital (internet), maka klausula baku harus diletakkan dan ditempatkan dalam urutan sebelum penutupan transaksi oleh konsumen, sehingga konsumen tidak dimungkinkan bertransaksi tanpa membuka halaman situs yang berisi klausula baku.

c. Bentuk klausula baku

Berhubungan dokumen dalam model standar yang memuat klausula baku senantiasa dalam bentuk tertulis atau digital, maka ukuran huruf (font) yang digunakan dalam menuliskan klausula baku tersebut harus dapat dibaca secara jelas. Selain itu, banyak dokumen yang berisi klausula baku terbuat dari kertas berkabon (carbonized paper) yang relatif tipis sehingga dalam pencetakan penulisan hurufnya menggunakan tinda berwarna muda (seperti warna abu muda) yang mengakibatkan isi dari tulisan klausula baku tidak dapat dibaca secara jelas oleh konsumen.

d. Pengungkapan klausula baku

Bahasa dan tata bahasa yang digunakan dalam merumuskan klausula baku dalam dokumen yang model standar harus mudah dimengerti oleh konsumen.
Bahasa dan tata bahasa yang digunakan adalah bahasa dan tata bahasa konsumen yang menjadi sasaran bidang usaha tersebut. Dalam hal dokumen dibuat dalam bahasa asing, harus dibuat terjemahannya secara resmi oleh penerjemah di sumpah. Jika di dalam model klausula baku terdapat istilah atau jargon tehnis yang hanya berlaku di kalangan terbatas, maka harus diungkapkan dengan bahasa dan tata bahasa umum yang mudah dimengerti oleh konsumen pada umumnya.

Dalam praktek penggunaan klausula baku kerap dilakukan oleh beberapa pelaku usaha dengan model dalam cetakan yang sudah dibuat standar. Di mana isi, letak, bentuk, dan pengungkapannya masih belum disesuaikan dengan ketentuan Pasal 18 ayat (1) Undang-Undang Perlindungan Konsumen.

Permasalan dalam pencantuman klausula baku bagi masyarakat (konsumen) terletak "tulisan", meskipun mengetahui bahwa apa yang terserat di dalam tanda bukti pembayaran maupun perjanjian merupakan suatu model yang sudah baku di buat oleh pelaku usaha.

Kata "baku" atau "standar" artinya tolok ukur yang dipakai sebagai patokan. Dalam hal ini klausula baku artinya ketentuan yang menjadi tolok ukur yang dipakai sebagai patokan atau pedoman bagi setiap konsumen yang mengadakan hubungan hukum dengan pelaku usaha (produsen). Yang dibakukan ialah model, rumusan dan ukuran (Sumarwan 2003). Sebagai bentuk baku, maka Badrulzaman (2005) dalam bukunya menyebutkan ciri-cirinya meniadakan dan membatasi kewajiban salah satu pihak, yaitu sebagai berikut.

1. Isinya ditetapkan secara sepihak oleh pihak (kreditur) yang posisinya relatif lebih kuat dari pihak (debitur) lainnya.

2. Pihak (debitur) lainnya sama sekali tidak menentukan isi perjanjian itu.

3. Terdorong oleh kebutuhannya (debitur) terpaksa menerima perjanjian itu. 
4. Bentuknya tertulis.

5. Dipersiapkan terlebih dahulu secara massal atau individu.

Model baku yang lahir dalam dunia bisnis dengan tujuan untuk kemudahan (kepraktisan) bagi para pihak yang bersangkutan, akan tetapi praktiknya tidak menunjukan kedudukan yang seimbang di antara kedua belah pihak. Dengan isi, letak, bentuk dalam pembuatan suatu tanda bukti pembayaran yang dibuat secara baku berarti setiap dokumen atau perjanjian yang dibuat oleh salah satu pihak yang lebih dominan dari pihak lainnya. Dikatakan bersifat baku karena klausula tersebut tidak dapat dan tidak mungkin dinegosiasikan atau ditawartawar oleh pihak lainnya (Widjaja dan Yani 2008).

Maka perlu Pembatasan atau larangan untuk memuat klausula-klausula baku tertentu dalam model baku pada transaksi perniagaan yang memberi perlindungan kepada konsumen. Hal ini dimaksudkan untuk mencegah terjadinya penyalahgunaan keadaan oleh pihak yang memiliki kedudukan lebih kuat pelaku usaha (produsen), yang pada akhirnya akan merugikan konsumen.

Menurut Jerry J. Philips dalam Miru (2011), ada beberapa hal yang perlu mendapat perhatian dalam konsep model baku, dimana pencantuman Klausula yang merugikan konsumen harus (a) menonjol dan jelas; (b) disampaikan tepat waktu; (c) pemenuhan tujuan-tujuan penting; (d) adil.

\section{a. Menonjol dan jelas}

Pengecualian terhadap tanggung gugat tidak dapat dibenarkan jika penulisannya tidak menonjol dan tidak jelas. Dengan demikian, maka penulisan pengecualian tanggung gugat yang ditulis di belakang suatu surat (dokumen) atau yang ditulis dengan cetak kecil, kemungkinan tidak efektif karena penulisan klausula tersebut tidak menonjol. Agar penulisan klausula dapat digolongkan menonjol, maka penulisannya dilakukan sedemikian rupa, sehingga konsumen yang berkepentingan akan memperhatikannya, misalnya dicetak dengan huruf besar atau dicetak dengan tulisan dan warna yang kontras, dan tentu saja hal ini dimuat dalam bagian penting dari perjanjian baku tersebut.

b. Disampaikan tepat waktu

Pengecualian tanggung gugat hanya efektif jika disampaikan tepat waktu sehigga setiap pengecualian itu harus disampaikan pada saat penutupan transaksi, sehingga merupakan bagian dari transaksi itu. Jadi bukan disampaikan setelah transaksi telah terjadi atau dengan kata lain telah diterima oleh konsumen.

c. Pemenuhan tujuan-tujuan penting.

Pembatasan tanggung gugat tidak dapat dilakukan jika pembatasan tersebut tidak akan memenuhi tujuan penting dari suatu jaminan, misalnya tanggung gugat terhadap cacat yang tersembunyi, tidak dapat dibatasi dalam batas waktu tertentu jika cacat tersembunyi tersebut tidak ditemukan dalam periode tersebut.

d. Adil

Jika pengadilan menemukan klausula baku yang tidak adil, maka pengadilan dapat menolak untuk melaksanakannya, atau melaksanakannya tanpa klausula yang tidak adil.

Dengan demikian, konsep perlindungan konsumen dalam bertransaksi dengan pelaku usaha yang memberikan bukti pada model atau bentuk-bentuk klausula baku haruslah dalam tata cara bahasa, tulisan dan cetakan yang dapat dibaca maupun dipahami serta dimengerti secara mudah dari klausula-klausula yang tertuang di dalam dokumen itu.

\section{Pembahasan}

\section{Implementasi Klausula Baku di Kota Bogor}

Berdasarkan data yang diperoleh pada pelaksanaan penelitian ini sebagai data pendukung, peneliti mendapatkan data dan informasi secara langsung mengenai pengetahuan masyarakat selaku konsumen tentang Klausula Baku. Lebih lanjut, agar 
lebih mengetahui sejauh mana efektivitas Undang-Undang Nomor 8 Tahun 1999 tentang Perlindungan Konsumen, khususnya ketentuan Pencantuman Klausula Baku [Pasal 18 ayat (1)], maka peneliti melakukan wawancara dengan pihak-pihak yang langsung berhubungan dengan pelaksanaan klausula baku di BPSK Kota Bogor, yaitu unsur Lembaga Perlindungan Konsumen Swadaya Masyarakat (LSM) yang ada di Kota Bogor dan unsur pemerintah yang membidangani Perlindungan Konsumen. Adapun rekapitulasi perkara penyelesaian sengketa konsumen mengenai klausula baku terdapat pada Tabel 1.

Tabel 1 Rekapitulasi perkara penyelesaian sengketa konsumen mengenai klausula baku di BPSK kota Bogor periode tahun 2005-2016.*

\begin{tabular}{|c|c|c|c|c|c|}
\hline No & Tahun & $\begin{array}{l}\text { Jumlah } \\
\text { Perkara }\end{array}$ & $\begin{array}{c}\text { Perkara } \\
\text { Klausula } \\
\text { Baku }\end{array}$ & Jenis Perkara & Ket \\
\hline 1. & 2005 & 4 & 1 & Perjanjian & Mediasi \\
\hline 2. & 2006 & 10 & 1 & Pemotongan uang pangkal & Mediasi \\
\hline 3. & 2007 & 13 & 1 & Label & Arbitrase \\
\hline 4. & 2008 & 16 & 2 & $\begin{array}{l}\text { Pembelian barang dan } \\
\text { penggantian barang }\end{array}$ & $\begin{array}{l}\text { Mediasi; } \\
\text { konsiliasi }\end{array}$ \\
\hline 5. & 2009 & 12 & 3 & $\begin{array}{l}\text { Penggantian barang (2) dan } \\
\text { pengembalian barang (1). }\end{array}$ & $\begin{array}{l}\text { Konsiliasi; } \\
\text { Mediasi }\end{array}$ \\
\hline 6. & 2010 & 12 & 9 & $\begin{array}{l}\text { Penggantian barang/uang (6) dan } \\
\text { pengembalian barang uang (2), } \\
\text { motor (1) }\end{array}$ & $\begin{array}{l}\text { Konsiliasi; } \\
\text { Mediasi }\end{array}$ \\
\hline 7. & 2011 & 10 & 2 & $\begin{array}{l}\text { Pengembalian uang dan } \\
\text { pengembalian mobil }\end{array}$ & $\begin{array}{l}\text { Arbitrase; } \\
\text { Ditolak }\end{array}$ \\
\hline 8. & 2012 & 16 & 6 & $\begin{array}{l}\text { Penggantian barang (5) dan } \\
\text { pengembalian uang (1) }\end{array}$ & $\begin{array}{l}\text { Ditolak; } \\
\text { Arbitrase }\end{array}$ \\
\hline 9. & 2013 & 16 & 3 & $\begin{array}{l}\text { Jasa listrik dan pengembalian } \\
\text { uang muka }\end{array}$ & $\begin{array}{l}\text { Arbitrase; } \\
\text { Mediasi }\end{array}$ \\
\hline 10. & 2014 & 20 & 6 & $\begin{array}{l}\text { Pengembalian barang/jasa yg tdk } \\
\text { sesuai dan pengembalian uang } \\
\text { muka }\end{array}$ & $\begin{array}{l}\text { Mediasi; } \\
\text { Arbitrase }\end{array}$ \\
\hline 11 & 2015 & 13 & 4 & $\begin{array}{l}\text { Barang tidak sesuai; klaim } \\
\text { asuransi; dan uang muka hangus }\end{array}$ & $\begin{array}{l}\text { Mediasi; } \\
\text { Konsiliasi }\end{array}$ \\
\hline 12 & $\begin{array}{l}2016 \\
\text { (Juni) }\end{array}$ & 12 & 6 & $\begin{array}{lcr}\text { Pelepasan } & \text { tanggung } & \text { jawab } \\
\text { produsen; } & \text { barang/jasa } & \text { tidak } \\
\text { sesuai } & & \end{array}$ & $\begin{array}{l}\text { Mediasi; } \\
\text { Dalam } \\
\text { proses }\end{array}$ \\
\hline
\end{tabular}

*Sumber: Sekretariat Badan Penyelesaian Sengket konsumen (BPSK) Kota Bogor.

Berdasarkan hasil penyebaran responden kepada masyarakat (konsumen) yang dilaksanakan secara acak (random) di wilayah kota Bogor, bahwa tingkat pengetahuan masyarakat kota terhadap klausula baku dinilai cukup mengetahui, terbukti dalam pelaksanaan transaksi perniagaan sering dijumpai dan bila terjadi perselisihan mengenai barang dan/atau jasa masih sulit untuk diselesaikan dalam hal tuntutan pengembalian barang/uang yang telah dibeli atau dinikmatinya. Hal ini dikarenakan pencantuman klausula baku yang tercantum di dalam tanda bukti 
transaksi atas barang dan/atau jasa secara jelas dan terang memberi protek terhadap pihak pelaku usaha (produsen) untuk dimintai pengembalian. Adapun responden konsumen terhadap klausula baku terdapat pada Tabel 2 .

Tabel 2 Tanggapan responden konsumen terhadap klausula baku di kota Bogor*

\begin{tabular}{|c|c|c|c|c|}
\hline Daftar Pertanyaan & \multicolumn{3}{|c|}{ Tanggapan } & \multirow[t]{2}{*}{ Ket } \\
\hline Mengetahui tentang & Tahu & Tidak Tahu & Dengar & \\
\hline klausula baku & 13 & 3 & 4 & - \\
\hline Dari mana & Baca & Berbelanja & Lainnya & \\
\hline klausula baku & 11 & 4 & 5 & - \\
\hline $\begin{array}{l}\text { Sering menjumpai } \\
\text { klausula baku }\end{array}$ & Sering & Jarang & $\begin{array}{l}\text { Tidak } \\
\text { Pernah }\end{array}$ & \\
\hline & 13 & 5 & 2 & \\
\hline Pernah kesulitan dalam & Pernah & Tidak Pernah & Lainnya & \\
\hline $\begin{array}{lr}\text { transaksi } & \text { adanya } \\
\text { pencantuman } & \text { klausula } \\
\text { baku } & \end{array}$ & 11 & 7 & 2 & - \\
\hline Masalah dalam & Kata-kata & Tulisan & Bentuk & \\
\hline $\begin{array}{l}\text { memahami klausula } \\
\text { baku }\end{array}$ & 6 & 11 & 3 & - \\
\hline Pernah keberatan atas & Pernah & Menerima & Lainnya & \\
\hline $\begin{array}{l}\text { pencantuman klausula } \\
\text { baku }\end{array}$ & 7 & 9 & 4 & - \\
\hline Setuju pencantuman & Setuju & Tidak Setuju & Lainnya & \\
\hline $\begin{array}{l}\text { klausula baku dalam } \\
\text { bukti transaksi }\end{array}$ & 7 & 8 & 4 & $\begin{array}{l}1 \\
\text { kosong }\end{array}$ \\
\hline Penggantian tuntutan & Diganti/dikembalikan & Tidak Diganti & Lainnya & \\
\hline $\begin{array}{lr}\text { kerugian } & \text { atas } \\
\text { pencantuman } & \text { klausula } \\
\text { baku } & \end{array}$ & 6 & 4 & 8 & $\begin{array}{l}2 \\
\text { kosong }\end{array}$ \\
\hline $\begin{array}{l}\text { Pernahkah melakukan } \\
\text { tindakan } \\
\text { kepada } \\
\text { lembaga/instansi atas } \\
\text { pencantuman klasula } \\
\text { baku }\end{array}$ & $\begin{array}{l}\text { Pernah } \\
4\end{array}$ & $\begin{array}{l}\text { Tidak Pernah } \\
16\end{array}$ & $\begin{array}{l}\text { Lainnya } \\
\text { - }\end{array}$ & \\
\hline $\begin{array}{l}\text { Lembaga/instansi yang } \\
\text { diminta bantuan dalam } \\
\text { penyelesaian tuntutan } \\
\text { klausula baku }\end{array}$ & Pengadilan & $\begin{array}{l}\text { Lembaga } \\
\text { Perlindungan } \\
\text { Konsumen } \\
9\end{array}$ & $\begin{array}{l}\text { Kantor } \\
\text { Pemerintah }\end{array}$ & $\begin{array}{l}11 \\
\text { Kosong }\end{array}$ \\
\hline
\end{tabular}

* Kuesioner yang disebar sebanyak 25 (dua puluh lima) dan yang kembali sebanyak 20 (dua puluh) dengan penyebaran di Kota Bogor secara acak (random), pada bulan Juni-Juli 2016.

Belum adanya suatu bentuk format sebagai model klausula baku yang dapat memberikan perlindungan terhadap konsumen, merupakan salah satu kekurangan dari ketentuan pencantuman klausula baku yang sesuai dengan Pasal 18 ayat (1) Undang-Undang Nomor 8 Tahun 1999 tentang Perlindungan Konsumen.

Menurut sumber data dari hasil wawancara dengan pihak LSM yang 
bergerak di bidang penanganan konsumen maupun pihak pemerintah sendiri yang membidangani perlindungan konsumen, yaitu wawancara dengan Bapak Marusaha (Direktur "LPKSM-Pelita Bangsa") dan Bapak Drs. Oktavian (Kepala Biro "LPK- Yudha Putra"), maupun Bapak Drs. Mangahit Sinaga, MM., selaku Kepala Bidang Perdagangan Dalam/Luar Negeri, Pengawasan Barang Beredar dan
Perlindungan Konsumen, Dinas Perindustrian dan Perdagangan Pemerintah Kota Bogor, yang juga menjabat sebagai Ketua BPSK Kota Bogor, yang pada intinya menyatakan bahwa masih belum adanya format pencantuman suatu model klausula baku yang sesuai dengan ketentuan UndangUndang Nomor 8 Tahun 1999 tentang Perlindungan Konsumen tersebut.

Tabel 3 Tanggapan hasil wawancara mengenai pelaksanaan klausula baku di kota Bogor

\begin{tabular}{|c|c|c|c|}
\hline \multirow{2}{*}{ Daftar Pertanyaan } & \multicolumn{2}{|c|}{ Jawaban } & \multirow{2}{*}{ Ket } \\
\hline & LPKSM & Pemerintah & \\
\hline $\begin{array}{lr}\text { Pengawasan } & \text { klausula } \\
\text { baku } & \text { telah } \\
\text { dilaksanakan } & \text { sesuai } \\
\text { dengan UUPK } & \end{array}$ & $\begin{array}{l}\text { Belum; } \\
\text { Masih kurang; } \\
\text { Perlu sosialisasi }\end{array}$ & Belum sepenuhnya & \\
\hline $\begin{array}{lr}\text { Pencantuman } & \text { klausula } \\
\text { baku telah } & \text { sesuai } \\
\text { dengan UUPK } & \end{array}$ & $\begin{array}{l}\text { Belum/tidak sesuai; } \\
\text { Lebih menguntungkan } \\
\text { (pelaku usaha) produsen }\end{array}$ & $\begin{array}{l}\text { Hampir semua belum } \\
\text { sesuai }\end{array}$ & - \\
\hline $\begin{array}{l}\text { Pernah } \\
\text { pemerintah/lembaga } \\
\text { lain memberikan } \\
\text { model klausula baku } \\
\text { yang harus digunakan } \\
\text { oleh pelaku usaha }\end{array}$ & $\begin{array}{l}\text { Belum ada panduan; } \\
\text { Normatif: telah ada } \\
\text { panduan; } \\
\text { Faktual: tidak ada format }\end{array}$ & $\begin{array}{l}\text { UUPK sudah memuat } \\
\text { aturan khusus }\end{array}$ & - \\
\hline $\begin{array}{l}\text { Bagaimana model } \\
\text { klausula baku yang } \\
\text { sesuai dengan UUPK }\end{array}$ & $\begin{array}{l}\text { Tidak merugikan pihak } \\
\text { lain (konsumen); } \\
\text { Format pencantuman } \\
\text { tidak melanggar } \\
\text { ketentuan UUPK }\end{array}$ & $\begin{array}{l}\text { Sebelum diberlakukan, } \\
\text { harus disetujui oleh BPSK } \\
\text { selaku pengawas }\end{array}$ & - \\
\hline $\begin{array}{l}\text { Pendapat/saran } \\
\text { lainnya }\end{array}$ & $\begin{array}{l}\text { Pemerintah lebih intens } \\
\text { melakukan/memfasilitasi } \\
\text { forum-forum } \\
\text { diskusi/kajian praktis } \\
\text { tentang klausula baku; } \\
\text { Adanya juklak yang } \\
\text { dibuat oleh pemerintah }\end{array}$ & $\begin{array}{l}\text { Dibuat juklak dan juknis } \\
\text { pelaksanaannya }\end{array}$ & - \\
\hline
\end{tabular}

Perlunya suatu Petunjuk Pelaksana (Juklak) dan Juknis (Petunjuk Tehnis) dari pemerintah dalam pelaksanaan pencantuman klausula baku ini sebagai bentuk dari peran pengawasan dari badan atau lembaga yang telah diberi kewenangan oleh undang-undang bersangkutan, agar dapat meminimalisir kerugian konsumen atas penerapan pencantuman klausula baku dengan tindakan preventif, edukasi dan sosialisasi pada tingkat pelaku usaha (produsen).

Perlunya gagasan sebagai konsep perlindungan konsumen untuk bertransaksi dalam perniagaan baik barang dan/atau jasa pada suatu model atau bentuk klausula- 
klausula baku dan tata cara bahasa, tulisan dan cetakan yang harus diberikan kepada konsumen sebagai dokumen dalam bertransaksi, sehingga masyarakat sebagai konsumen dapat membaca, memahami dan mengerti secara mudah dari klausulaklausula yang tertuang di dalam tanda bukti transaksi.

\section{KESIMPULAN DAN IMPLIKASI}

\section{Kesimpulan}

Berikut beberapa kesimpulan yang diperoleh dari hasil penelitian.

1. Di wilayah kota Bogor masih beredarnya tanda-tanda bukti transaksi berupa kuitansi/bon, karcis, lembar pembayaran dan berbagai bentuk lainnya, di mana kesemua bukti-bukti pembayaran transaksi yang berupa Model Klausula Baku lebih banyak beredar yang belum disesuaikan dengan ketentuan larangan pencantuman klausula sebagaimana diamanatkan oleh Undang-Undang Perlindungan Konsumen. Hanya sebagian pelaku usaha (produsen) yang telah menyesuaikan dengan cara model penulisan saja yang lebih dapat di baca dengan tanda yang mudah di lihat, tetapi belum menyesuaikan dengan ketentuan larangan pencantuman klausula baku dimaksud.

2. Perlunya suatu model klausula baku yang dapat memberi perlindungan terhadap konsumen yang bersifat berlaku secara umum, khususnya di wilayah kota Bogor ini. Cara pemberian model klausula yang merupakan pedoman yang dapat digunakan yaitu sesuai dengan ketentuan Undang-Undang Perlindungan Konsumen yang tidak merugikan terhadap konsumen. Adapun bentuk tanda bukti transaksi itu, harus dapat mudah di baca, mudah di lihat, dan mudah dipahami oleh konsumen secara sekilas, yang bahannya dapat tahan secara lama tidak mudah pudar. Sehingga ketentuan larangan pencantuman klausula baku berdasarkan Undang-
Undang Perlindungan Konsumen yang dianggap belum efektif dalam implementasinya ini dapat terealisasikan.

\section{Implikasi}

Berikut beberapa implikasi yang diperoleh dari hasil penelitian.

1. Perlunya pemerintah, khususnya Pemerintah Kota Bogor, dalam hal ini Dinas Perindustrian dan Perdagangan yang membidangi perlindungan konsumen memberlakukan suatu model klausula baku yang dapat berlaku secara standar bagi para pelaku usaha dalam membuat tanda bukti transaksi barang dan/atau jasa yang disesuaikan dengan ketentuan yang berlaku dalam UndangUndang Perlindungan Konsumen, yaitu dengan petunjuk pelaksana (Juklak) dan Petunjuk Tehnis (Juknis) sebagai pedoman untuk tertera pada tanda bukti transaksi itu oleh pelaku usaha. Serta mensosialisasikannya kepada masyarakat selaku konsumen dan pelaku usaha yang ada.

2. Kewenangan BPSK (Kota Bogor) sesuai dengan amanat Undang-Undang Perlindungan Konsumen dalam hal menjalankan tugas dan wewenangnya, yaitu salah satunya adalah "Melaksanakan pengawasan klausula baku" dapat lebih ditegaskan dalam bentuk aturan pelaksana yang dibuat oleh Kementerian Perdagangan R.I., sehingga dapat berlaku secara umum di setiap BPSK Kabupaten/Kota yang ada. Dengan demikian tugas pengawasan tersebut dapat terimplementasikan secara pasti dan efektif dalam rangka memberikan perlindungan terhadap konsumen.

\section{UCAPAN TERIMA KASIH}

Ucapan terima kasih sebesar-besarnya kami sampaikan kepada Koordinasi Perguruan Tinggi Swasta Wilayah IV, Direktorat Jenderal Riset Dan Pengembangan, Kementerian Riset, Teknologi dan 
Pendidikan Tinggi, Rektor dan Direktur LPPM, serta Dekan Fakultas Hukum Universitas Djuanda Bogor, Ketua Badan Penyelesaian Sengketa Konsumen Kota Bogor, serta unsur-unsurnya, Kepala Dinas Perindustrian dan Perdagangan Pemerintah Daerah Kota Bogor, dan semua pihak yang telah membantu terlaksananya penelitian ini.

\section{DAFTAR PUSTAKA}

Miru A. 2011. Prinsip-prinsip perlindungan hukum bagi konsumen di Indonesia. Raja Grafindo Persada, Jakarta.

Anonim. 2003. Pedoman klausula baku di bidang perbankan yang disempurnakan. Direktorat Perlindungan Konsumen, Direktorat Jenderal Perdagangandalam Negeri, Departemen Perindustrian dan Perdagangan, Tahun 2003.

Bank Indonesia. Himpunan Ketentuan Perlindungan Nasabah. Bank Indonesia.

Tobing DML. 2007. Parkir + Perlindungan Hukum Konsumen. Timpani Publishing, Jakarta.

Direktorat Perlindungan Konsumen. 2001. Panduan pedoman penyelenggaraan perlindungan konsumen. Direktorat Perdagangan Dalam Negeri, Departemen Perindustrian Dan Perdagangan, Jakarta.

Direktorat Perlindungan Konsumen. 2002. Pedoman klausula baku dibidang telekomunikasi. Direktorat Perdagangan Dalam Negeri, Departemen Perindustrian Dan Perdagangan, Jakarta.

Widjaja G dan A Yani. 2008. Hukum tentang perlindungan konsumen. Gramedia Pustaka Utama, Jakarta.

Sjahputra I. 2010. Perlindungan konsumen dalam transaksi elektronik. Alumni, Bandung.

Ibrahim J. 2006. Teori dan metodologi penelitian hukum normatif. Cetakan kedua. Bayumedia Publishing, Malang.
Keputusan Menteri Perindustrian dan Perdagangan Nomor 350/MPP/Kep/12/2001 tanggal 10 Desember 2001 tentang Pelaksanaan Tugas dan Wewenang Badan Penyelesaian Sengketa Konsumen (BPSK). Keputusan Presiden Republik Indonesia Nomor 108 Tahun 2004 tanggal 18 Oktober 2008 tentang Pembentukan Badan Penyelesaian Sengketa Konsumen pada Pemerintah Kota Kupang, Kota Samarinda, Kota Sukabumi, Kota Bogor, Kota Kediri, Kota Mataram, Kota Palangkaraya dan pada Kabupaten Kupang, Kabupaten Balitung, Kabupaten Sukabumi, Kabupaten Bulungan, Kabupaten Serang, Kabupaten Ogan Komering Ulu dan Kabupaten Jeneponto;

Kitab Undang-Undang Hukum Perdata (Burgelijke Wetboek);

Kurniawan, Problematika Kedudukan dan Kekuatan Putusan Badan Penyelesaian Sengketa Konsumen, UB Press, malang, 2011.

Badrulzaman MD. 2005. Aneka hukum bisnis. Alumni, Bandung.

Siahaan NHT. 2005. Hukum konsumenperlindungan konsumen dan tanggung jawab produk. Panta Rei, Jakarta.

Peraturan Pemerintah Republik Indonesia Nomor 59 Tahun 2001 tentang Lembaga Perlindungan Konsumen Swadaya Masyarakat.

Marzuki PM. 2005. Penelitian hukum. Prenada Media, Jakarta.

Sumarwan U. 2003. Perilaku konsumenteori dan penerapannya dalam pemasaran. Penerbit Ghalia Indonesia, Jakarta.

Undang-Undang Dasar 1945.

Undang-Undang Nomor 8 Tahun 1999 tentang Perlindungan Konsumen.

Priyono Y. 2015. Perlindungan konsumen dalam klaim asuransi barang pada pembiayaan kendaraan bermotor. Jurnal Ilmiah LIVING LAW. Volume 7, Nomor 2, Oktober 2015. 